\author{
Justyna Kobus \\ Uniwersytet im. Adama Mickiewicza w Poznaniu \\ Instytut Filologii Polskiej \\ ORCID: 0000-0002-4094-2743; e-mail: jusper@amu.edu.pl
}

\title{
Leksyka mikropola tematycznego MUCHA w języku mieszkańców okolic Pobiedzisk w środkowej Wielkopolsce
}

\begin{abstract}
Abstrakt: Autorka artykułu omawia wąską grupę słownictwa skupionego wokół tematu MUCHA. Przytaczane w tekście poświadczenia terenowe pochodzą z najnowszych eksploracji w okolicach Pobiedzisk, miasta położonego w niedalekiej odległości od Poznania. Autorka podkreśla wartość współpracy ze szkołami w pozyskiwaniu lokalnej leksyki.
\end{abstract}

Słowa kluczowe: gwara, język mieszkańców wsi, pole tematyczne.

\begin{abstract}
FLY lexis in the thematic microfield in the language spoken by the inhabitants of Pobiedziska in central Wielkopolska. The author of the article discusses a narrow group of vocabulary focused around the topic of FLY. The field credentials come from the most recent exploration in the area of Pobiedziska, a town located in the vicinity of Poznań. The author emphasizes the value of cooperation with schools in acquiring the local lexis.
\end{abstract}

Keywords: dialect, language of rural residents, thematic field.

Współpraca ze szkołami, która jest wyraźną od wielu lat cechą dialektologii poznańskiej, dowodzi ogromnej potrzeby prowadzenia intensywnych badań terenowych w Wielkopolsce. Wiele takich wspólnych działań zwieńczonych jest słownikiem języka mieszkańców badanej okolicy - dotychczas powstało sześć takich leksykonów ${ }^{1}$ (siódmy jest w opracowaniu).

Wspomniany $\mathrm{w}$ tytule artykułu teren (okolice Pobiedzisk) to obszar położony w środkowej części Wielkopolski (27 km na wschód od Poznania), objęty eksploracjami w ramach współpracy pomiędzy Pracownią Dialektologiczną w Instytucie Filologii Polskiej UAM a Szkołą Podstawową im. Kazimierza Odnowiciela w Pobiedziskach.

${ }^{1}$ Dotychczas w cyklu „Wielkopolskie Słowniki Regionalne” ukazały się: Słownik języka mieszkańców okolic Czerniejewa. Praca na roli $i$ w gospodarstwie, pod red. Justyny Kobus i Magdaleny Stępień, Wydawnictwo PSP, Poznań, 2018; Stownik języka mieszkańców okolic Gniezna. Święta, wierzenia i przesądy, pod red. J. Kobus i T. Gniazdowskiego, Wydawnictwo PSP, Poznań, 2018; Gospodarz. Słownik języka mieszkańców powiatu kolskiego, pod red. B. Osowskiego, Wydawnictwo PTPN, Poznań, 2018; Gospodyni. Słownik języka mieszkańców powiatu kolskiego, pod red. B. Osowskiego, Wydawnictwo PTPN, Poznań, 2018; Słownik mieszkańców ziemi tukowskiej. Praca na roli $i$ w gospodarstwie, pod red. J. Sierociuka, Wydawnictwo PSP, Poznań, 2019; W kuchni u pleszewian. Słownik języka i kultury mieszkańców powiatu pleszewskiego, pod red. B. Osowskiego, Wydawnictwo PTPN, Poznań, 2019. 
Obydwa ośrodki podjęły wspólny trud badawczy w ramach regionalnego projektu edukacyjnego pt. Praca na roli $i$ w gospodarstwie - badamy język mieszkańców okolic Pobiedzisk. Trud ten był ukierunkowany na powstanie Słownika języka mieszkańców okolic Pobiedzisk. Praca na roli i w gospodarstwie - kolejnego w cyklu „Wielkopolskie Słowniki Regionalne" (planowany rok wydania 2021). W ramach półtorarocznych badań terenowych (luty 2019 - sierpień 2020) zostały pozyskane obszerne materiały (z 9 miejscowości) ${ }^{2}$, które z przyczyn objętościowych nie mogły zostać w całości zamieszczone w opracowywanym tomie słownika. Zanim jednak trafią do druku w innej publikacji, chciałabym częściowo o nich wspomnieć przy okazji niniejszego artykułu.

Tytułem objaśnienia rozwiązań terminologicznych stosowanych przeze mnie do opisu konkretnej grupy słownictwa - pole tematyczne, zgodnie z koncepcją Teresy Skubalanki (1966, 16), rozwiniętą następnie przez Jerzego Sierociuka, rozumiem jako zbiór wyrazów powiązanych na drodze skojarzeń, słowem jest ono „budowane na zasadzie asocjacji, skojarzenia, jest [...] pojemne znaczeniowo i może być bardzo rozległe, zawierające w sobie wiele szczególnie wyraźnie zakreślonych pól leksykalno-semantycznych" (Sierociuk 2003, 133); w obrębie pola tematycznego wyodrębnić można grupę leksyki skupionej wokół jednego z jego elementów, wówczas mamy do czynienia z subpolem tematycznym; natomiast mikropole tematyczne to jeszcze bardziej zawężona grupa wyrazów w obrębie subpola będąca zarazem najmniejszym zbiorem tematycznym w obrębie pola. I tak np. opisywane w tym artykule mikropole tematyczne MUCHA można traktować jako część subpola tematycznego OWADY w polu tematycznym PRZYRODA (por. Kobus 2015, 25).

Literatura przedmiotu raczej skromnie opisuje muchy i to, co jest z nimi związane. W słownikach wielkopolskich (przeważnie amatorskich) leksyka mikropola MUCHA pojawia się zasadniczo okazjonalnie ${ }^{3}$. Także $\mathrm{w}$ profesjonalnych słownikach $\mathrm{z}$ terenu Wielkopolski (SPodróżna, WSR ${ }^{4}$ ) sytuacja nie wygląda dużo lepiej ${ }^{5}$. Zdecydowanie więcej uwagi poświęcają tym uciążliwym owadom przysłowia polskie, a nawet literatura piękna. W dociekaniach dialektologicznych mucha zaistniała jako przedmiot badań zespołu Atlasu językowego polskiego Podkarpacia (AJPP, m. 225. „Muchy [zwykle też Gen. pl] [Musca domestica]") oraz zespołu Atlasu języka i kultury ludowej Wielkopolski (AJKLW-II, m. 193. „Duża mucha o niebieskawogranatowym połysku [Calliphora]"; dalej także: AJKLW). W AJPP podano formy mianownika i dopełniacza obu liczb nazwy mucha na południu Polski, zaś w AJKLW zwrócono uwagę na nazwy konkretnego rodzaju muchy.

$\mathrm{Z}$ innych pozycji językoznawczych podejmujących problematykę związaną z nazwami owadów warto wymienić pracę doktorską Marcina Maciołka pt. Kształtowanie

\footnotetext{
2 Zbadane w projekcie punkty badawcze to: miasto gminne Pobiedziska (Pob) oraz wsie: Latalice (Lat), Gołunin (Głn), Główna (Głw), Podarzewo (Pdo), Polska Wieś (PIW), Węglewo (Węg), Zbierkowo (Zbk), Złotniczki (Złt).

${ }^{3}$ Wśród słowniczków amatorskich, które przejrzałam pod kątem poszukiwań badanego słownictwa, znalazły się: SJut, SJar, SBis, SPał.

${ }^{4}$ Cykl „Wielkopolskie Słowniki Regionalne”.

5 W przypadku WSR powodem nielicznych notacji konkretnej grupy leksykalnej jest zakres tematyczny słowników.
} 
się nazw owadów w języku polskim. Procesy nominacyjne a językowy obraz świata (Maciołek 2012) - znajdziemy tu liczne przykłady występowania rozmaitych owadów w literaturze pięknej (i nie tylko), we frazeologii i paremiologii; nie ma tu jednak materiału gwarowego - mimo to odwołam się do niektórych fragmentów tej pracy.

Pozyskany współcześnie w terenie materiał pozwolił wyodrębnić w mikropolu tematycznym MUCHA następujące tematy: rodzaje much; formy rozwojowe muchy; to, co służy do zwalczania much; reakcje bydła na działalność much. Przyjrzyjmy się pokrótce nazwom w poszczególnych grupach.

\section{Rodzaje much: mucha (domowa), mucha końska / końska, gza / bon k, robacz- nica / gromodnica, mszyca.}

Pierwsza obserwacja, dotycząca wymienionych nazw, wiąże się z dwojakim użyciem wyrazu mucha (w D 1. mn. częsta forma muchów). Informatorzy stosują go zarówno w odniesieniu do ogółu owadów przypominających budową muchę, ale i - mówiąc mucha - mają na myśli konkretny rodzaj (czy też gatunek) tegoż pasożyta, czyli najczęściej spotykaną w gospodarstwach muchę domową (Musca domestica).

Wśród much krwiopijnych badani wyróżniają muchę końska (jusznicę deszczową - Haematopota pluvialis), zwaną po prostu końska oraz bonki nazywane też gzami (chodzi o dwa różne gatunki owadów pasożytujących na bydle domowym - Hypoderma bovis lub Tabanus bovinus). Zwykle nazwy $b o^{n} k$ i gzy stosowane są wymiennie przez naszych informatorów. Co ciekawe, gzy w liczbie pojedynczej przyjmują w Wielkopolsce rodzaj męski (giez) lub żeński $(g z a)$. W opisywanym terenie zanotowaliśmy formę żeńską, którą Słownik gwar polskich PAN (SGP) poświadcza wyłącznie na Śląsku. $B o^{n} k a$ rejestruje natomiast $\mathrm{w}$ powiatach złotowskim, kaliskim, konińskim, nowotomyskim, czyli poza środkową Wielkopolską.

Interesujące okazały się poświadczenia nazw 'dużej muchy, która składa jaja na mięsie'. W okolicach Pobiedzisk odnotowaliśmy dwa poświadczenia: robacznica, gromodnica. Nazwy tegoż owada były przedmiotem dociekań zespołu AJKLW. W tomie I atlasu znajdziemy mapę 193. „Duża mucha o niebieskawogranatowym połysku (Calliphora)". Dla badanej przez nas współcześnie okolicy, czyli w atlasowym punkcie 41 (Promno - dziś teren gminy Pobiedziska) zaznaczono typ gromadnica; nie odnotowano tu wówczas zapisanej współcześnie nazwy robacznica (ani w punkcie 41, ani w jego najbliższym promieniu). Poświadczenie dla nazwy gromadnica notuje także SGP za AJKLW; w MSGP znajdziemy zaś hasło robacznica m.in. dla Wielkopolski.

Interesująco przedstawia się sytuacja leksemu mszyca, pierwotnie stanowił on zdrobnienie wyrazu mucha - określał małą muchę - dziś zleksykalizował się i nazywa konkretny gatunek niewielkich rozmiarów much pasożytujących na młodych liściach, gałązkach, pędach roślin. Uwagę na ten stan rzeczy zwrócił M. Maciołek w swojej rozprawie:

z punktu widzenia słowotwórstwa historycznego formą deminutywną od wyrazu mucha jest nie tylko rzeczownik muszka, ale również mszyca. Formę tę utworzono za pomocą sufiksu -ica, który dawniej mógł pełnić różnorodne funkcje znaczeniowe (zresztą do dziś jest polifunkcyjny), a jedną z nich było właśnie tworzenie zdrobnień [...] Jak czytamy w Gramatyce historycznej języka polskiego trzech autorów, „dotąd jako jedyny przykład tej zamarłej formacji zachowała się mszyca, która jednak rozluźniła swój związek i w budowie, i w znacze- 


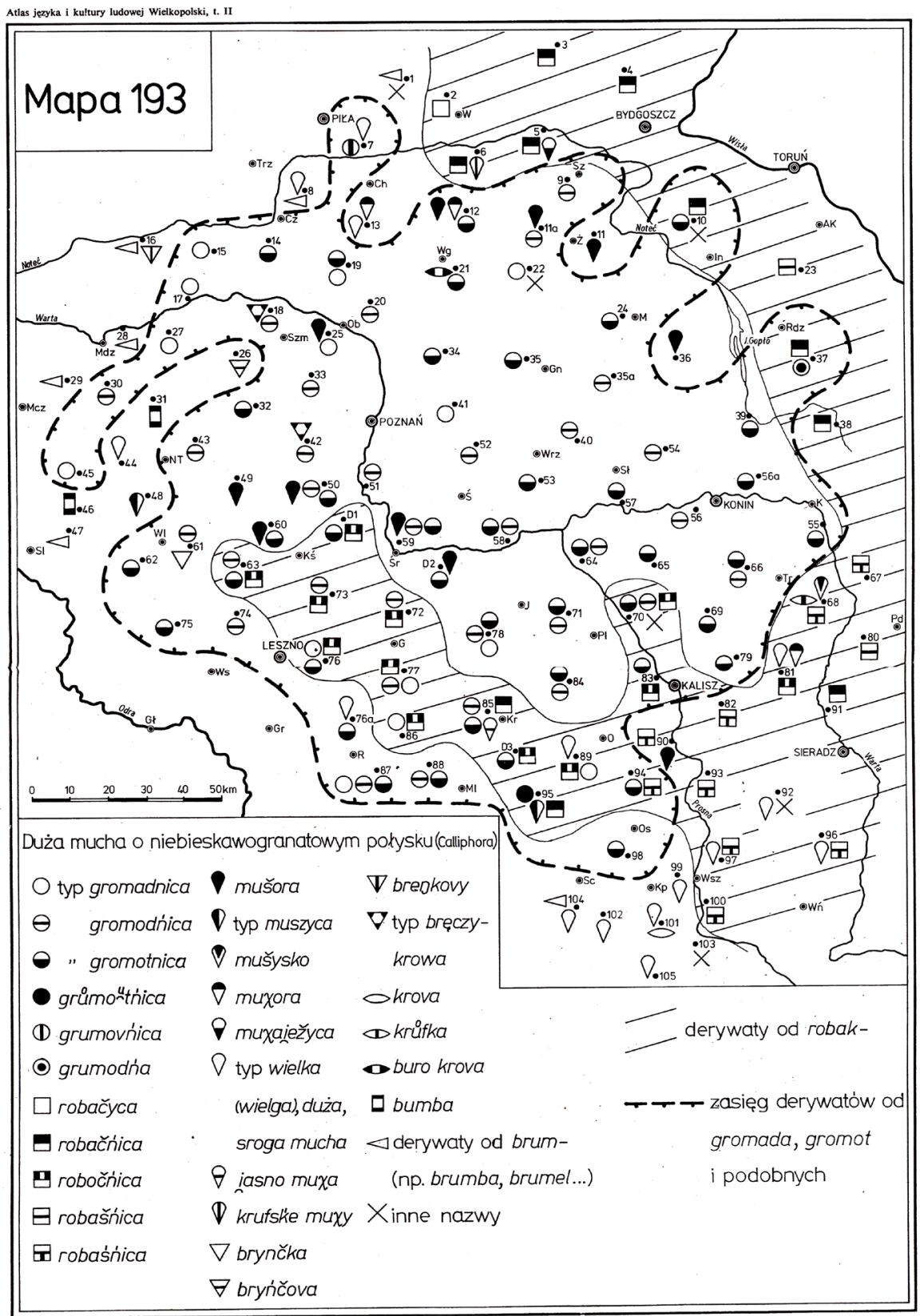

Zakład Narodowy im. Ossolinskich - Wydawnictwo Polskiej Akademii Nauk

Wroclawska Drukarnia Naukor

Fot. 1. Mapa 193. 'Duża mucha o niebieskawogranatowym połysku (Calliphora)' - AJKLW-II 
niu z podstawowym rzeczownikiem mucha" [Klemensiewicz, Lehr-Spławiński, Urbańczyk 1965: 218] (Maciołek 2012, 241-242).

Mszyce obecnie stanowią osobne mikropole, którego dalej tu rozwijać nie będę. Uznałam jednak, że ze względu na prymarne znaczenie wyrazu, należy o nim wspomnieć.

W kolejnych passusach przytaczam artykuły hasłowe przygotowane z myślą o kolejnym tomie słownika WSR poświęconego szeroko rozumianej przyrodzie dzikiej i oswojonej, które dają wgląd w pozyskany materiał terenowy:

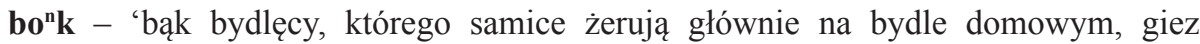
bydlęcy': pamientam jag roz mi kazali krowy paź a im sie nie chciało to tylko jak były goron $^{n}$ zki to robili bzz ... to krowy jak dostaty "ogóny zadarty to wszyskie do dómu pouciekaty ... no ale krowy uciekty a i tag je wygnat z powrotym ... [...] bónki ... takie bón$^{n} k i$ byy ... [...] no ... obzykaty téz ... no ... (Złt); zob. gza, mucha.

gromodnica - 'duża mucha żerująca na mięsie i składająca na nim jaja': gromodnice podobno ... a to so ${ }^{m}$ takie duże muchy no to po poznańsku byty gromodnice ... [...] no ... to jes wtaśnie ta duża mucha ... z tymi owadami ... z tymi larwami $w$ mie ${ }^{n}$ sie ... czuje mie $e^{n}$ so $i$ przylatuje ... nie wiem jakoź ma taki we ${ }^{n}$ ch ... wyostrzony na świeże mie $e^{n} k o$... (Pob); zob. mucha, robacznica.

gza - 'bąk bydlęcy, którego samice żerują głównie na bydle domowym, giez bydlęcy': no gzy to so ${ }^{m}$ wtaśnie te owady co atakujo ${ }^{m}$ krowy i co na przyktad ... naj$c z e^{n}$ ściej krowy ... i pod skóro ${ }^{m}$ wyle gnie sie owad ... to jes taki ... taka ... duży ... duży to jes guz taki na tym i jes tyn ... (Głn); no duża mucha która składa te jajka jakby na krowie ... jakoś przez uko ${ }^{n}$ szenie i później le gnie sie z tego te gzy ... gzy sie le ${ }^{n}$ gno $^{m} . .$. (Głn); no bo to jednak [robactwo] takiego stwora to tyż menczy ... nie ... czy to kónia jag miat te gzy ... te te co na tego pogryzty czy czy krowy co co miaty tyż te te na tego ... pod skóro ${ }^{m}$... no to te tak samo my czyło ... no ... tak samo my czyło ... (Węg); gzy ... to kóń nie wim ... [...] kóń chyba miot $w$ żołon $d k u$... bo ón jak to usiadło to jaj skłodato ... ciło tyż ... ale jaja i to swyndziało ... to koń wygryzol sobie ... nie ... i koń chyba miot $w$ żoło ${ }^{n} d k u$ ale nie wim jak ... [...] krowa tyż se zlizała to potym $w$ okolicach krzyza ... nie ... kry"gostupa ... take ... take guziołki ... to tyz ksionżke bym musiot to bym panu pokozot ... i to ... takie ... tako larwa byta ... nie ... [...] jak tak byto na skórze i ta butelka była z takóm tegó i taj ji tu puknot to to wydusiło ... to tam krowe zabolato ... nie ... ale wydusit ... [...] to byty gzy ... (Pob); gzy ... [...] duze brzen czonce muchy ... (Pob); no to so ${ }^{m}$ te owady atakujo ce ... gzy-gzy-gzy-gzy ... no ... latajo ${ }^{n} \mathrm{ce}$... fruwajonce jeszcze oczywiście ... no ... [...] no mi sie wydaje że tak sie powinno mówić gza ... ale czy gez? (!) ... nie wiem ... gza chyba ... (Pob); zob. bo ${ }^{\mathrm{n}} \mathrm{k}$, mucha.

końska (mucha) - 'rodzaj muchy odżywiającej się krwią zwierząt i ludzi, boleśnie kąsającej; jusznica deszczowa': [mucha końska] to jes duża mucha atakujonca te ... konie ... wtaśnie przed deszczem czy takich tam ... [...] w ogóle jag jes wilgotno ... taki ... pod lasem ... na tonce ... taka ... wilgotne powietrze wtedy jes ... (Pob); dwa dni mnie końska nie ugryzła ... (Pob); zob. mucha, mucha końska.

mszyca - 'małe muszki, których larwy gęsto osiadają na młodych roślinach i częściach zielonych roślin, wysysając z nich sok, co powoduje obumarcie rośliny': mszyce ... [...] te które atakujo ${ }^{m}$ młode cze ści roślin ... (Głw); no mszyce to so ${ }^{m}$ bardzo 
malutkie takie szkodniki które wypijajom jakby sok ... wody słodkie czy tego z roślin ... z liści roślin najczen ściej ... (Głn); no to jez mszyca ... [...] no ... to so ${ }^{m}$ te małe muszki $i$ w ogóle ... które takie so ${ }^{m}$ bardzo lepkie... takie na różah nawed można na wszystkich kwiatach też ... (Pob) (Pdo).

mucha - 'uciążliwy owad przenoszący choroby; muchy masowo wlatują do mieszkań i budynków gospodarskich, uprzykrzając życie ich mieszkańców': bywało tez kiedyś że zasłaniało sie okna tylko otwierało na przykład drzwi i jakimiś tam dużymi nawet gatenziami machało sie po mieszkaniu bo muchy zawsze leciały do widnego... bo $w$ pomieszczeniu było ciemno a jedne drzwi byly otwarte $i$ tam $w$ naste ${ }^{m}$ pnym pomieszczeniu byto widno no to wtedy te muchy tam leciaty ... (Głn); no duża mucha która składa te jajka jakby na krowie ... jakoś przez ukonszenie i później le ${ }^{n}$ gnie sie z tego te gzy ... gzy sie le gno ${ }^{m}$... (Głn); na misie to muchów to zaź ino trzeba uważać ... Boże ... bo tyn zapah juz ... [...] to zielone muchy takie ... (Złt); gromodnice podobno... a to som takie duże muchy no to po poznańsku byty gromodnice ... [...] no ... to jes właśnie ta duża mucha ... z tymi owadami ... z tymi larwami $w$ mie ${ }^{n}$ sie ... czuje mie $e^{n}$ so i przylatuj ... nie wiem jakoź ma taki we $e^{n}$ h ... wyostrzony na świeże mie ${ }^{n}$ sko ... (Pob); no to sieci na muchy $w$ takim razie pajon $k$ be $e^{n} d z i e$... robi ... no ... (Pob); gza chyba ... [...] to jes duża mucha atakujon ca te ... konie ... wtaśnie przed deszczem czy takich tam ...

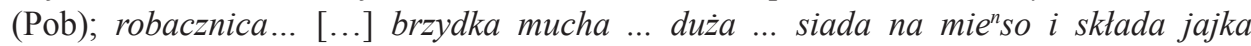
z tego wyle gajo $^{m}$ sie takie mate glizdki ... (Pob); gzy... [...] duże brze czo $^{n}$ ce muchy ... (Pob); [mucha końska] to duża mucha która wypija krew u koni ... u krów i nawed u człowieka ... (Pob) (Głw); zob. bo kn, gromodnica, gza, końska, mucha końska, muszka.

mucha końska - 'mucha odżywiająca się krwią zwierząt i ludzi, boleśnie kąsająca; jusznica deszczowa': so ${ }^{m}$ też muchy takie ... te na te mówimy muchy końskie ... takie duże ... (Głn); my tė mówimy na to że to so ${ }^{m}$ muchy końskie i tyle ... muchy końskie ... nie wiem no ... muchy końskie ... ale fachowo nie wiem ... (Głn) (Głw) (Pob); zob. końska, mucha.

robacznica - 'duża mucha składająca jaja na mięsie’: robacznica... [...] brzydka mucha ... duża ... siada na mie ${ }^{n}$ so $i$ sktada jajka z tego wyle gajo $^{m}$ sie takie małe glizdki ... (Pob); zob. gromodnica, mucha.

2. Formy rozwojowe muchy: jajko / jajo, larwa / glizdka, muszka, owad (dorosły), le gno $^{\text {ńć }}$ (sie).

Cykl rozwojowy muchy - jak większości owadów - obejmuje stadium jaja, larwy, imago. Taki też stan wiedzy pokazali informatorzy z okolic Pobiedzisk. Badani opowiadali o składanych przez muchy jajkach / jajach, z których $l e^{n}$ gno $^{m}$ sie larwy / glizd$k i$, a te zamieniają się w dorosłe owady (muchy lub muszki - te ostatnie, jeśli są niewielkich rozmiarów).

Nie odniosę się tu do innych źródeł niż nasze poświadczenia terenowe, gdyż żadna z powyższych nazw nie była opisywana przez AJKLW czy inne źródła dotyczące gwar wielkopolskich.

Poniżej przywołuję materiały $\mathrm{z}$ okolic Pobiedzisk w postaci gotowych artykułów hasłowych:

glizdka - 'forma przejściowa w rozwoju owadów, znajdująca się w okresie po wyjściu z jaja, a przed przepoczwarczeniem w postać dorosłą’: robacznica... [...] 
brzydka mucha ... duża ... siada na mie ${ }^{n}$ so i sktada jajka z tego wyle gajo $^{m}$ sie takie małe glizdki ... (Pob); zob. larwa.

jajko - 'pierwsze stadium w cyklu rozrodczym owadów': no duża mucha która składa te jajka jakby na krowie ... jakoś przez ukonszenie i później lengnie sie z tego te gzy ... gzy sie le gno $^{m}$... (Głn); robacznica... [...] brzydka mucha ... duża ... siada na mie $^{n}$ so i składa jajka z tego wyle gajo $^{m}$ sie takie mate glizdki ... (Pob); zob. jajo.

jajo - 'pierwsze stadium w cyklu rozrodczym owadów': gzy ... to kón nie wim ... [...] kóń chyba miot $w \dot{z}$ ołond $d k u$... bo ón jak to usiadło to jaj skłodało ... ciło tyż ... ale jaja $i$ to $s w y^{n} d z i a ł o$... to koń wygryzol sobie ... nie ... i koń chyba miot $w$ żołon $d k u$ ale nie wim jak ... (Pob); zob. jajko.

larwa - 'forma przejściowa w rozwoju owadów, znajdująca się w okresie po wyjściu z jaja, a przed przepoczwarczeniem': krowa tyż se zlizała to potym $w$ okolicach krzyza ... nie ... kry" gostupa ... take ... take guziotki ... to tyż ksion żke bym musiot to bym panu pokozot ... $i$ to ... takie ... tako larwa byta ... nie ... i to jak by wypadto to by znowu mucha z tego była ... bo to tam petny okrez musiol trwać żeby to sie przeksztatciło ... nie ... i to taki ... taki jakby wrzód byt na skórze ... tako górka i dziura sie robiła ... nie ... bo ón potym tyn ... tyn ... ten ... no to pasożyt taki byt ... nie ... tak tako ... no tako larwa ... jo wim jak by to powiedzieć ... tako dtugo byta i tak z centymetr może gruba może ... może centymetra nie ... nie ... i taki ... taki ... taki kształd miała tag jag tezka ... o ... nie ... taki ksztatt ... to nojlepi byto jak to ... nie ... butelke ... pukno ńc ... to wydusito ... wyleciot to ... nie ... bo jak by to po pewnym czasie to by som wyszed ... nie ... by znowu byt $i$ znowu ... by naste ${ }^{m}$ pne koło sie robiło ... nie ... naste ${ }^{m}$ pne pokolynie ... a tak to zabit ... nie ... nie cekot oż som be dzie ... no ... jak tak było na skórze i ta butelka była z takóm tegó i taj ji tu puknoł to to wydusito ... to tam krowe zabolato ... nie ... ale wydusit ... [...] to byty gzy ... (Pob); no ... to jes wtaśnie ta duża mucha ... z tymi owadami ... z tymi larwami $w$ mie $e^{n}$ sie ... czuje mie $e^{n}$ so i przylatuje ... nie wiem jakoź ma taki we ${ }^{n}$ ch ... wyostrzony na świeże mie ${ }^{n}$ sko ... (Pob) (Głw); zob. glizdka.

le $^{\text {nnonć }}$ (sie) - 'tu: wychodzić z jaja': no duża mucha która składa te jajka jakby na krowie ... jakoś przez ukonszenie i później le gnie sie z tego te gzy ... gzy sie le $e^{n}$ gno $^{m}$ ... (Głn); no pławito sie [jajka] ... no ... a potym jak sie ly gly to sie wyklujóm ... (Pob); zob. wykluć, wykluwać, wylengać sie.

muszka - 'niewielkich rozmiarów mucha': b.c. (Pob); zob. mucha.

owad - 'tu: dokuczliwy insekt': no ... to jes właśnie ta duża mucha ... z tymi owadami ... z tymi larwami $w$ mie $e^{n}$ sie ... czuje mie ${ }^{n}$ so i przylatuje ... nie wiem jakoź ma taki we ${ }^{n}$ ch ... wyostrzony na świeże mie ${ }^{n}$ sko ... (Pob); no to so ${ }^{m}$ te owady atakujo ${ }^{n} c e . .$. gzy-gzy-gzy-gzy ... no ... latajonce ... fruwajonce jeszcze oczywiście ... no ... (Pob).

3. To, co służy do zwalczania much: pajon ${ }^{n}$, pajęczyna / sieć, lepce, klapka / tapka, muchotapka, padać.

Muchy nie są mile widzianymi owadami w domostwach czy na pastwiskach. $\mathrm{Z}$ tego też względu są tępione przez człowieka na różne sposoby. Działania ludzkie wspiera natura w postaci naturalnego wroga much - pajo ${ }^{n} k a$, który tka paje ${ }^{n} c z y n e$ zwaną też siecio $^{m}$. Do ludzkich wytworów siejących pogrom wśród much badani mieszkańcy okolic Pobiedzisk zaliczyli: lepce zawieszane pod sufitem paski lepkiej taśmy lub papieru, przyczepiane do lampy lub rozstawiane na szafach i parapetach, klapke 
zwaną też $\operatorname{lapko}^{m}$ (na muchy), która służy zgnieceniu muchy za pomocą uderzenia, oraz muchołpaki, czyli pojemniki lub naczynia wypełnione substancją wabiącą muchy do wnętrza, w którym czeka je śmierć. W okolicach Pobiedzisk mówi się, że muchy padajo $^{m}$ m.in. na skutek działania substancji chemicznej, z głodu itp.

Także i ta tematyka nie ma szerszego kontekstu w literaturze przedmiotu, toteż przytaczam dalej materiały w formie opracowanych artykułów hasłowych (według zasad WSR):

klapka - 'ręczny przyrząd do zabijania much za pomocą uderzenia': zabijano je [muchy] klapkami ... tapkami ... (Głw); jo mówie bombowiedz loto ... i klapke zaraz ... o ... a to nie jes bombowiec to jez normalna [mucha] ... (Pob); łapko ${ }^{m}$... znaczy sie $k_{\text {lapko }}^{m}$... no ... tak sie tego ... nie ... [...] no ... klapka ... klapka na muchy ... (Pob); zob. łapka.

lepce - 'taśma rozwijana w pomieszczeniach, do której przyklejają się muchy': zawieszano takie lepce (!) [na muchy] ... na ... na tym sie lepity ... ale także ... ale teraz so ${ }^{m}$ takie środki że ... że można je wytruć ... (Pob).

lapka - 'ręczny przyrząd do zabijania much za pomocą uderzenia': zabijano je [muchy] klapkami ... tapkami ... (Głw); łapko ${ }^{m}$... znaczy sie klapko ${ }^{m}$... no ... tak sie tego ... nie ... [...] no ... klapka ... klapka na muchy ... (Pob); zob. klapka.

muchołapka - 'naczynie lub pojemnik z substancją wabiącą muchy, w którym czeka je śmierć': no muchy najczen'ściej padajo ${ }^{m}$ jak som jakieś tam muchołapki... (Głn).

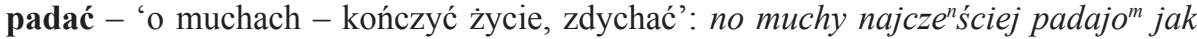
so ${ }^{m}$ jakieś tam muchołapki... (Głn).

pajenezyna - 'nić wytwarzana przez pająka i tkana na kształt sieci': b.c. (Pob); zob. sieć.

pajon $^{n} \mathbf{k}$ - 'pożyteczny stawonóg tkający sieci i polujący na owady': no to sieci na muchy $w$ takim razie pajon $k$ be $e^{n} d z i e$... robi ... no ... (Pob).

sieć - 'nić wytwarzana przez pająka i tkana na kształt sieci': no to sieci na muchy $w$ takim razie pajon ${ }^{n}$ be $e^{n}$ zie ... robi ... no ... (Pob); zob. paje ${ }^{n}$ czyna.

4. Reakcje bydła na działalność much: bzykać sie, obzykać, gzić sie.

Zmasowana liczba owadów z grupy krwiopijnych na niewielkim obszarze, szczególnie na pastwisku, potrafi przysporzyć niemałych kłopotów gospodarzowi. Na terenach przeznaczonych pod wypas bydła obecność gzów czy bonków oznacza zwykle niechybny popłoch wśród zwierząt domowych, szczególnie w upalny dzień. Zmasowany atak pasożytów kończy się często ucieczką bydła do domu. Informatorzy określili takie gwałtowne zachowanie zwierząt wyrazami: bzykać sie, obzykać, gzić sie. Nadmienię, że w okolicach Czerniejewa (gm. Gniezno) - przy okazji wcześniejszego projektu edukacyjnego - notowaliśmy w takim samym znaczeniu określenie wybzykać sie (zob. SCz), co nie dziwi, gdyż Pobiedziska i Czerniejewo dzieli odległość zaledwie $16 \mathrm{~km}$.

Hasła bzykać się oraz gzić się notuje SGP dla terenów położonych na północ od Gniezna, czyli dla poddialektu północnej Wielkopolski (właściwie pogranicza z poddialektem środkowowielkopolskim). Ponadto, tak niektóre notowane przez nas poświadczenia, jak i zachowanie zdenerwowanych stad znane są literaturze fachowej i przysłowiom, o czym wspomina M. Maciołek w swojej rozprawie, m.in. w następującym fragmencie: 
To niespokojne zachowanie zwierząt kąsanych przez gzy nazywa w polszczyźnie utworzony na bazie rzeczownika giez czasownik postfiksalno-paradygmatyczny gzić się. Jego motywację objaśnia Gustaw Belke w dziele pt. O owadach szkodliwych gospodarstwu wiejskiemu $i$ sposobach ustrzeżenia się od nich lub zmniejszenia ich liczby (1861): „Należą [chodzi o gza i gzika - dop. moj - M.M.] do tych owadów bydło szczególniej prześladujących, które jaja swoje pod skórę a nawet wewnątrz ciał bydlęcych składają, a przy tej czynności boleśnie zwierzęta kłując, sprawiają, że w rożne strony z podniesionymi ogonami gwałtownie się rozbiegają, co zwykle gżeniem się bydła gospodarze zowią" [BelOwad 1861: 82] (Maciołek 2012, 213).

W kolejnych akapitach podaję artykuły hasłowe poświęcone wymienionym wyrazom i wyrażeniom:

bzykać sie - 'o krowach: płoszyć się na skutek uciążliwego, zmasowanego ataku owadów kąsających, gzów bydlęcych’: u nas sie kiedyź mówiło że krowy sie bzykajom ... (Głn); zob. gzić sie, obzykać.

gzić sie - 'o krowach: płoszyć się na skutek uciążliwego, zmasowanego ataku owadów kąsających, gzów bydlęcych’: b.c. (Pob); zob. bzykać sie, obzykać.

obzykać - 'o gzach: spłoszyć krowy na skutek uciążliwego, zmasowanego ataku':

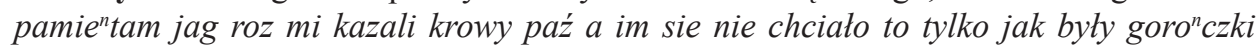
to robili bzz ... to krowy jak dostały "ogóny zadarly to wszyskie do dómu pouciekały ... no ale krowy uciekty a $i$ tag je wygnat z powrotym ... [...] bónki ... takie bónki byy ... [...] no ... obzykały tė̇ [mówiono] ... no ... (Złt); zob. bzykać sie, gzić sie.

Opisane słownictwo mówi nam wiele o przeobrażeniach w obrębie języka mieszkańców wsi. Współczesne badania terenowe pokazały, że w mowie badanych informatorów mamy jeszcze sporo słownictwa starego, od lat poświadczanego w niezmienionym znaczeniu (np. gzić sie). Zaobserwowaliśmy także poszerzenie znaczenia niektórych wyrazów (np. łapka do zabijania much), które wcześniej notowano w innych kontekstach, ale i mamy do czynienia ze słownictwem wcześniej nienotowanym (np. klapka do zabijania much).

Można jedynie żałować, że tak mało materiału odnośnie do opisywanego tu mikropola tematycznego znajduje się $\mathrm{w}$ dostępnych słownikach $\mathrm{z}$ terenu Wielkopolski. Na cztery sprawdzone słowniki amatorskie najczęściej notowanym hasłem (o takim samym lub zbliżonym znaczeniu jak omawiane wyżej) jest bąk (SBis, SPał) oraz gromodnica (w różnych wariantach fonetycznych) (SJut, SJar), znacznie rzadziej pojawia się mucha (SBis) i pająk (SBis). Władysław Brzeziński odnotował w takich samych znaczeniach jak omawiane wyżej: bąk, mszyca, mucha, bzykać się oraz w innym znaczeniu, ale w tym samym mikropolu muchołapka 'lep na muchy'; z kolei gzić (się) zapisał jako określenie ucieczki czy szybkiego oddalenia się z jakiegoś miejsca, ale bez konotacji dotyczących bydła (zob. SPodróżna). W dotychczasowych publikacjach z serii WSR odnotowano natomiast: mucha (SGpni), le gno ${ }^{n} \dot{c}$ sie / lingnońć sie $\mathrm{w}$ znaczeniu dotyczącym także owadów (choć bez konotacji z muchami) (SGpni), bon $k$ (SGprz), gza (SGprz), padać (o umieraniu zwierząt, lecz bez konotacji z owadami) (SGprz), giez (SCz), bzyk 'bąk bydlęcy, którego samice żerują głównie na bydle domowym, giez bydlęcy’ (SCz), wybzykać (w odniesieniu do krów) (SCz). 
Już te ogólne obserwacje dowodzą potrzeby prowadzenia dalszych eksploracji terenowych. Współpraca ze szkołami jest doskonałym przykładem skutecznego pozyskiwania lokalnego słownictwa. Dzięki skoordynowanym działaniom możemy śledzić żywotność i przeobrażenia leksyki o charakterze gwarowym czy regionalnym w danej okolicy. Wartość współpracy, przynoszącej takie właśnie efekty, jest nie do przecenienia.

\section{Literatura}

AJKLW, Atlas języka i kultury ludowej Wielkopolski, t. I-VI, pod red. Z. Sobierajskiego, J. Burszty, Wrocław, 1979-1991; t. VII-XI, pod red. Z. Sobierajskiego, Wrocław - Poznań 1992-2005.

AJKLW-II, Atlas języka i kultury ludowej Wielkopolski, t. II: CZŁOWIEK - PRZYRODA, pod red. Z. Sobierajskiego, J. Burszty, Wrocław 1979.

AJPP, Małecki M., Nitsch K. (1934), Atlas językowy polskiego Podkarpacia, Kraków.

MSGP, Mały słownik gwar polskich, pod red. J. Wronicz, Kraków 2009.

SBis, Stownik gwary biskupiańskiej, pod red. M. Giery i K. Jańczak, Stara Krobia 2005.

SCz, Stownik języka mieszkańców okolic Czerniejewa. Praca na roli i w gospodarstwie, pod red.

J. Kobus i M. Stępień, Poznań 2018.

SGn, Słownik języka mieszkańców okolic Gniezna. Święta, wierzenia i przesądy, pod red. J. Kobus i T. Gniazdowskiego, Poznań 2018.

SGP, Stownik gwar polskich PAN, t. I, z. 1-3, pod red. M. Karasia, Wrocław, 1977, 1981; t. II, z. 1(4)-3(6), pod red. J. Reichana, S. Urbańczyka, Wrocław, 1983, 1986; t. III, z. 1(7)-3(9), pod red. J. Reichana, S. Urbańczyka, Wrocław, 1989-1991; t. IV, z. 1(10)-3(12), pod red. J. Reichana, S. Urbańczyka, Kraków, 1992-1993; t. V, z. 1(13)-3(15), pod red. J. Reichana, S. Urbańczyka, Kraków, 1994, 1996, 1998; t. VI, z. 1(16)-4(19), pod red. J. Okoniowej, J. Reichana, Kraków, 2001-2004; t. VII, z. 1(20)-4(23), pod red. J. Okoniowej, J. Reichana, B. Grabki, Kraków, 2005-2007, 2010, t. VIII, z. 1(24)-4(27), pod red. J. Okoniowej, J. Reichana, B. Grabki, Kraków, 2011-2013, t. IX, z. 1(28)-4(31), pod red. B. Grabki, R. Kucharzyk, J. Okoniowej, J. Reichana, Kraków, 2014-2017; t. X, z. 1(32)-2(33), pod red. B. Grabki, R. Kucharzyk, Kraków 2018-2019.

SGpni, Gospodyni. Stownik języka mieszkańców powiatu kolskiego, pod red. B. Osowskiego, Poznań 2018.

SGprz, Gospodarz. Stownik języka mieszkańców powiatu kolskiego, pod red. B. Osowskiego, Poznań 2018.

SJar, Podeszwa J. (2014), Stownik gwary Ziemi Jarocińskiej, Jarocin.

SJut, Żyto H. (2013), Słownik gwary jutrosińskiej, [w:] W. Gawroński, H. Żyto, Jutrosińska wiara i gwara, Jutrosin.

SŁk, Słownik mieszkańców ziemi tukowskiej. Praca na roli $i w$ gospodarstwie, pod red. J. Sierociuka, Poznań 2019.

SPał, Binkowski M.K. (2011), Mój słownik gwary pałuckiej, Żnin.

SPl, W kuchni u pleszewian. Słownik języka i kultury mieszkańców powiatu pleszewskiego, pod red. B. Osowskiego, Poznań 2019.

SPob, Stownika języka mieszkańców okolic Pobiedzisk. Praca na roli $i$ w gospodarstwie, pod red. J. Kobus i A. Migdałek, Poznań [w druku]. 
SPodróżna, Brzeziński W. (1987-2009), Słownictwo krajniackie. Słownik gwary wsi Podróżna w Złotowskiem, t. I-V, Wrocław [i in.].

Belke G. (1861), O owadach szkodliwych gospodarstwu wiejskiemu i sposobach ustrzeżenia się od nich lub zmniejszenia ich liczby, Żytomierz.

Klemensiewicz Z., Lehr-Spławiński T., Urbańczyk S. (1965), Gramatyka historyczna języka polskiego, Warszawa.

Kobus J. (2015), Kierunki $i$ dynamika zmian $w$ języku mieszkańców wielkopolskich wsi na przełomie wieków XX i XXI, Poznań.

Maciołek M. (2012), Ksztaltowanie się nazw owadów w języku polskim. Procesy nominacyjne a językowy obraz świata, praca doktorska napisana pod kierunkiem prof. UŚ, dr hab. Jolanty Tambor, Katowice.

Sierociuk J. (2003), Założenia metodologiczne badań języka wsi, „Poznańskie Spotkania Językoznawcze”, t. XI, pod red. Z. Krążyńskiej i Z. Zagórskiego, Poznań, s. 131-136.

Skubalanka T. (1966), Słownictwo miłosne poezji J. Słowackiego na tle tradycji, Toruń. 